\title{
Systematic literature review of integrated community case management and the private sector in Africa: Relevant experiences and potential next steps
}

Phyllis Awor ${ }^{1,2}$, Jane Miller ${ }^{3}$, Stefan Peterson ${ }^{1,4,5}$

${ }^{1}$ School of Public Health, College of Health Sciences, Makerere University, Kampala, Uganda

${ }^{2}$ Centre for International Health, Global Public Health and Primary Care, University of Bergen, Norway

${ }^{3}$ Malaria and Child Survival Department, Population Services International, Nairobi, Kenya

${ }^{4}$ Global Health, Karolinska Institutet, Stockholm, Sweden

${ }^{5}$ International Maternal and Child Health Unit, Uppsala University, Uppsala, Sweden

\section{Correspondence to:}

Phyllis Awor

School of Public Health, College of Health

Sciences

Makerere University, PO Box 7072

Kampala, Uganda

aworphyllis@yahoo.co.uk
Background Despite substantial investments made over the past 40 years in low income countries, governments cannot be viewed as the principal health care provider in many countries. Evidence on the role of the private sector in the delivery of health services is becoming increasingly available. In this study, we set out to determine the extent to which the private sector has been utilized in providing integrated care for sick children under 5 years of age with community-acquired malaria, pneumonia or diarrhoea.

Methods We reviewed the published literature for integrated community case management (iCCM) related experiences within both the public and private sector. We searched PubMed and Google/ Google Scholar for all relevant literature until July 2014. The search terms used were "malaria", "pneumonia", "diarrhoea", "private sector" and "community case management".

Results A total of 383 articles referred to malaria, pneumonia or diarrhoea in the private sector. The large majority of these studies (290) were only malaria related. Most of the iCCM-related studies evaluated introduction of only malaria drugs and/or diagnostics into the private sector. Only one study evaluated the introduction of drugs and diagnostics for malaria, pneumonia and diarrhoea in the private sector. In contrast, most iCCM-related studies in the public sector directly reported on community case management of 2 or more of the illnesses.

Conclusions While the private sector is an important source of care for children in low income countries, little has been done to harness the potential of this sector in improving access to care for non-malaria-associated fever in children within the community. It would be logical for iCCM programs to expand their activities to include the private sector to achieve higher population coverage. An implementation research agenda for private sector integrated care of febrile childhood illness needs to be developed and implemented in conjunction with private sector intervention programs. 
Despite substantial investments made over the past 40 years in low income countries, governments cannot be viewed as the principal health care provider in many countries [1]. Evidence on the role of the private sector in the delivery of health services is becoming more available $[2,3]$.

Integrated community case management (iCCM) of malaria, pneumonia and diarrhoea is a public sector strategy aimed at improving timely access to treatment for sick children in resource limited settings [4]. It is now being scaled up across the African continent, largely by means of community health workers. However, in many low income countries, the first source of care for most children with fever is usually the private sector, mainly comprising of small drug shops which sell medicines as a business [5-8]. The quality of care provided at this level is also known to be low $[7,9]$.

We set out to determine the extent to which the private sector has been utilized in providing integrated care for sick children under- 5 years of age with community-acquired malaria, pneumonia or diarrhoea.

\section{METHODS}

Where relevant, we followed the Preferred Reporting Items for Systematic Reviews and Meta-Analyses (PRISMA) statement and checklist in designing and reporting our review [10]. We reviewed the published literature for iCCM related experiences within both the public and private sector. We searched PubMed and Google/ Google Scholar for all relevant literature until July 2014. The search terms used were "malaria", "pneumonia", "diarrhoea", "private sector" and "community case management". In PubMed, we used the advanced search option. We combined the search terms and searched for private sector and public sector studies, respectively, using the following search phrases: "(((malaria) OR pneumonia) OR diarrhoea) AND private sector" and "(((diarrhoea) OR pneumonia) OR malaria) AND community case management."

In the first step, we screened the titles of all the articles retrieved from both searches. The abstracts of the titles that included malaria, pneumonia or diarrhoea in the public or private sector were then selected and read. Finally, for articles where abstracts reported results from evaluation studies that met our inclusion criteria, we read through the full text to confirm this. Wherever clarification was needed, we re-read through the full text of the relevant articles. We included all peer-reviewed studies reporting the evaluation of any intervention with drugs and or diagnostics for malaria, pneumonia or diarrhoea, or a combination of those illnesses in children within the private or public sector. We included the following types of studies: randomized controlled trials, quasi experimental studies, and studies with a pre-post design with or without a control group. We also accessed grey literature by searching websites of organizations involved in private sector work. The number and characteristics of studies in both private and public sector, reporting iCCM-related interventions either separately or in an integrated manner, are reported.

\section{RESULTS}

A total of 944 papers were found by searching the databases. These included 385 private sector and 559 public sector papers. An additional 2 papers were included from the grey literature. After screening, 13 private sector and 49 public sector papers remained for final analysis (Figure 1). The final papers included were from studies conducted in 20 countries: 44 in Africa, 16 in Asia and 2 in Latin America. Most studies were conducted in rural settings.

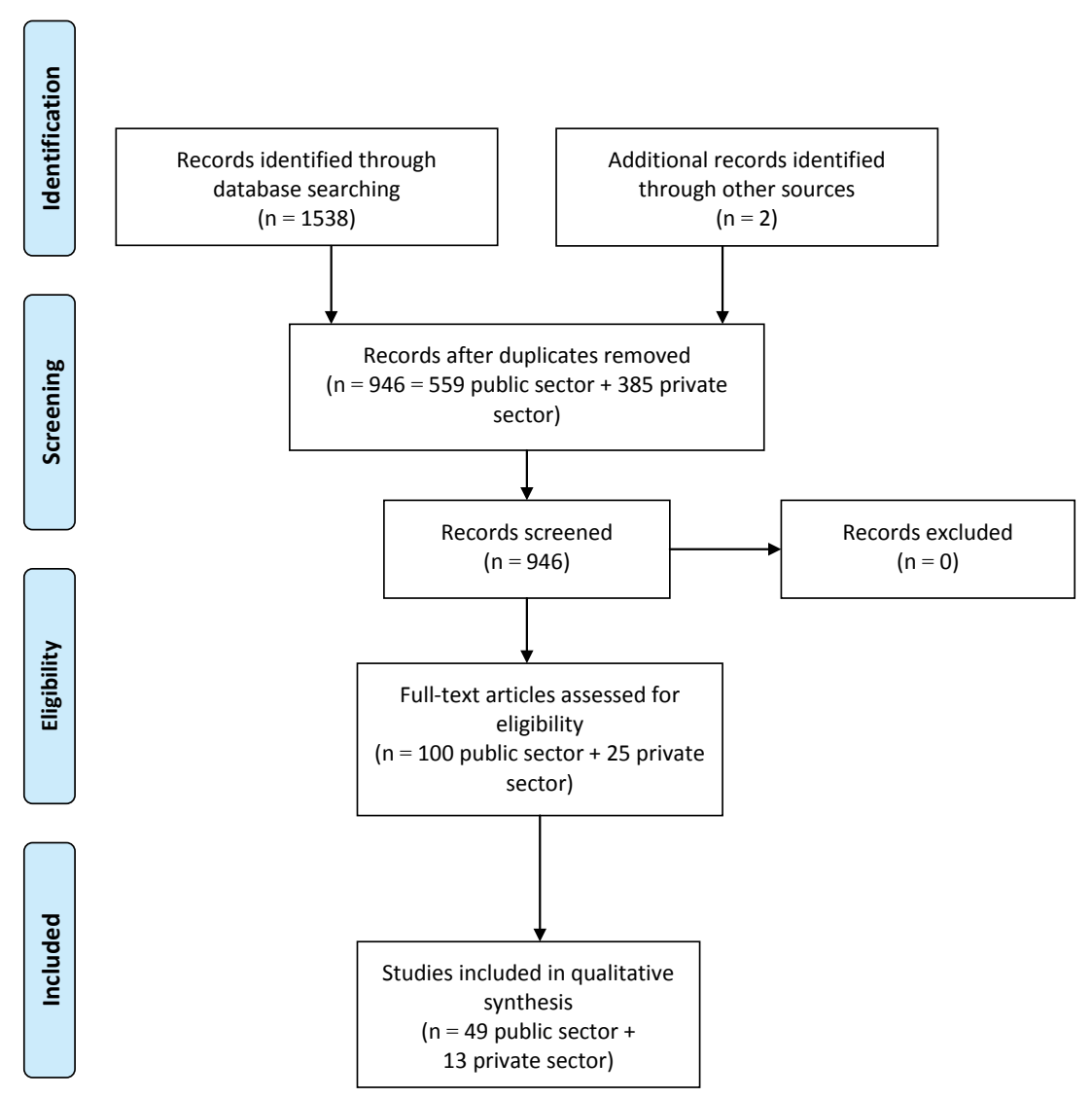

Figure 1. Flow diagram of literature search and screening. 
Table 1. Studies reporting evaluation of interventions for malaria, pneumonia or diarrhoea in the private sector, by disease category

\begin{tabular}{|c|c|c|}
\hline Disease(s) & Author & TitLE \\
\hline \multirow[t]{11}{*}{ Malaria } & Thomson et al. 2014 [11] & $\begin{array}{l}\text { Has Tanzania embraced the green leaf? Results from outlet and household surveys before and after } \\
\text { implementation of the Affordable Medicines Facility-malaria }\end{array}$ \\
\hline & Ikwuobe et al. 2013 [12] & $\begin{array}{l}\text { The impact of rapid malaria diagnostic tests upon anti-malarial sales in community pharmacies } \\
\text { in Gwagwalada, Nigeria }\end{array}$ \\
\hline & Kangwana et al. 2013 [13] & $\begin{array}{l}\text { The effect of an anti-malarial subsidy programme on the quality of service provision of artemis- } \\
\text { inin-based combination therapy in Kenya: a cluster-randomized, controlled trial }\end{array}$ \\
\hline & Tougher et al. 2012 [14] & $\begin{array}{l}\text { Effect of the Affordable Medicines Facility-malaria (AMFm) on the availability, price, and market } \\
\text { share of quality-assured artemisinin-based combination therapies in seven countries: a before- } \\
\text { and-after analysis of outlet survey data }\end{array}$ \\
\hline & Talisuna et al. 2012 [15] & $\begin{array}{l}\text { Closing the access barrier for effective anti-malarials in the private sector in rural Uganda: consor- } \\
\text { tium for artemisin-based combination therapy (ACT) private sector subsidy (CAPSS) pilot study }\end{array}$ \\
\hline & Yeung et al. 2011 [16] & $\begin{array}{l}\text { Socially marketed rapid diagnostic tests and ACT in the private sector: ten years of experience in } \\
\text { Cambodia }\end{array}$ \\
\hline & Littrel et al. 2011 [17] & $\begin{array}{l}\text { Case management of malaria fever in Cambodia: results from national anti-malarial outlet and } \\
\text { household surveys }\end{array}$ \\
\hline & Rutta et al. 2011 [18] & $\begin{array}{l}\text { Increasing access to subsidized artemisinin-based combination therapy through accredited drug } \\
\text { dispensing outlets in Tanzania }\end{array}$ \\
\hline & Kangwana et al. 2011 [19] & $\begin{array}{l}\text { The impact of retail-sector delivery of artemether-lumefantrine on malaria treatment of children } \\
\text { under five in Kenya: a cluster randomized controlled trial }\end{array}$ \\
\hline & Alba et al. 2010 [20] & $\begin{array}{l}\text { Improvements in access to malaria treatment in Tanzania after switch to artemisinin combination } \\
\text { therapy and the introduction of accredited drug dispensing outlets - a provider perspective }\end{array}$ \\
\hline & Abuya et al. 2010 [21] & $\begin{array}{l}\text { Evaluating different dimensions of programme effectiveness for private medicine retailer malaria } \\
\text { control interventions in Kenya }\end{array}$ \\
\hline Pneumonia & & No articles \\
\hline Diarrhoea & Larson et al. 2012 [22] & $\begin{array}{l}\text { Scaling up zinc treatment of childhood diarrhoea in Bangladesh: theoretical and practical consid- } \\
\text { erations guiding the SUZY Project }\end{array}$ \\
\hline $\begin{array}{l}\text { Malaria, pneumonia } \\
\text { and diarrhoea inte- } \\
\text { grated care }\end{array}$ & Awor et al. 2014 [23] & $\begin{array}{l}\text { Increased access to care and appropriateness of treatment at private sector drug shops with inte- } \\
\text { grated management of malaria, pneumonia and diarrhoea: a quasi-experimental study in Uganda }\end{array}$ \\
\hline
\end{tabular}

We found 385 articles referring to malaria, pneumonia or diarrhoea in the private sector. The majority of these studies (290) were only malaria related. Thirteen studies met the inclusion criteria (Table 1) and most of them (86\%) evaluated only introduction of malaria drugs and/or diagnostics into the private sector [11-21]. There were no articles reporting community level interventions for pneumonia treatment or diagnosis within the private sector. Only one study evaluated a diarrhoea treatment intervention, using both private and public sector [22].

Moreover, there were limited iCCM-related experiences in the private sector within the published literature, where diagnosis of non-malaria fever was made and alternative treatment provided to sick children. We are aware of one study introducing diagnostics and pre-packaged drugs for malaria, pneumonia and diarrhoea into private sector drug shops [23]. Population Services International (PSI) is implementing iCCM in several countries [24] and Larsen et al. (in preparation) will report on improving quality of private sector case management of diarrhoea, pneumonia and malaria in Uganda using a Social Franchising approach.

In contrast, of 559 articles retrieved when we searched for iCCM-related experiences in the public sector, the major- ity were directly related to CCM of 2 or more illnesses (malaria, pneumonia and diarrhoea). Forty nine articles met the inclusion criteria of studies evaluating an intervention with drugs or diagnostics in the community, for malaria, pneumonia or diarrhoea. Only 13 (26\%) of the included studies on ICCM in the public sector evaluated an intervention for malaria only (Table 2).

\section{DISCUSSION}

Experiences with integrated community case management of malaria, pneumonia and diarrhoea by means of public sector community health workers is increasingly reflected in the literature. Meanwhile, interventions in the private sector have so far targeted largely malaria diagnosis and management.

The community case management experience using community health workers in Africa was initiated by the Home Management of Malaria experience [36]. However, challenged by symptom overlap with other febrile illness [74] and spurred by the largely Asian success in community management of pneumonia [75], it then followed the ex- 
Table 2. Studies reporting evaluation of interventions for malaria, pneumonia or diarrhoea in the public sector, by disease category

$$
\text { I }
$$

\section{DISEASE(s) \\ Malaria}

.

Aurhor
Siekmans et al. 2013 [25]
Ndiaye et al. 2013 [26]

Blanas et al. 2013 [27]

Thiam et al. 2012 [28]

Lim et al. $2012[29]$ TIIIE Community case management of malaria: a pro-poor intervention in rural Kenya

Community case management in malaria: review and perspectives after four years of operational experience in Saraya district, south-east Senegal

Barriers to community case management of malaria in Saraya, Senegal: training, and supplychains

Scale-up of home-based management of malaria based on rapid diagnostic tests and artemisinin-based combination therapy in a resource-poor country: results in Senegal

tial contributions of Village Malaria Workers

Tine et al. 2011 [30] Impact of combining intermittent preventive treatment with home management of malaria in children less than 10 years in a rural area of Senegal: a cluster randomized trial

Chanda et al. 2011 [31] Community case management of malaria using artemisin-based combination therapy (ACT) and rapid diagnostic tests (RDT) in two districts in Zambia: achieving high adherence to test results using community health workers

Mubi et al. 2011 [32] Malaria rapid testing by community health workers is effective and safe for targeting malaria treatment: randomised cross-over trial in Tanzania

Nusungwa-Sabiiti et al. Home-based management of fever and malaria treatment practices in Uganda 2007 [33]

Chinbuah et al. 2006 [34] Feasibility and acceptability of the use of artemether-lumefantrine in the home management of uncomplicated malaria in 6-59 month-old children in Ghana

Kolaczinski et al. 2006 [35] Adherence of community caretakers of children to pre-packaged antimalarial medicines (HOMAPAK) among internally displaced people in Gulu district, Uganda

Kidane and Morrow 2000 [36] Teaching mothers to provide home treatment of malaria in Tigray, Ethiopia: a randomised trial

Kalyango et al. 2013 [37] Integrated community case management of malaria and pneumonia

Increases prompt and appropriate treatment for pneumonia symptoms in children under five years in Eastern Uganda

Noordam et al. 2014 [38] The use of counting beads to improve the classification of fast breathing in low-resource settings: a multi-country review

Bari et al. 2011 [39] Community case management of severe pneumonia with oral amoxicillin in children aged 2-59 months in Haripur district, Pakistan: a cluster randomised trial

Soofi et al. 2012 [40] Effectiveness of community case management of severe pneumonia with oral amoxicillin in children aged 2-59 months in Matiari district, rural Pakistan: a cluster-randomised controlled trial

Sylla et al. 2007 [41] Low level educated community health workers training: a strategy to improve children access to acute respiratory treatment in Senegal

Kallander et al. 2006 [42] Can community health workers and caretakers recognize pneumonia in children? Experiences from western Uganda

\begin{tabular}{|c|c|}
\hline Hadi et al. 2002 [43] & Diagnosis of pneumonia by community health volunteers: experience of BRAC, Bangladesh \\
\hline Mehnaz et al. 1997 [44] & $\begin{array}{l}\text { Detection and management of pneumonia by community health workers-a community in- } \\
\text { tervention study in Rehri village, Pakistan }\end{array}$ \\
\hline Bang et al. 1990 [45] & $\begin{array}{l}\text { Reduction in pneumonia mortality and total childhood mortality by means of community- } \\
\text { based intervention trial in Gadchiroli, India }\end{array}$ \\
\hline Khan et al. 1990 [46] & $\begin{array}{l}\text { Acute respiratory infections in children: a case management intervention in Abbottabad Dis- } \\
\text { trict, Pakistan }\end{array}$ \\
\hline Fagbule et al. 1994 [47] & $\begin{array}{l}\text { Acute respiratory infections in Nigerian children: prospective cohort study of incidence and } \\
\text { case management }\end{array}$ \\
\hline Bang et al. 1993 [48] & Pneumonia in neonates: can it be managed in the community? \\
\hline Bang et al. 1994 [49] & Management of childhood pneumonia by traditional birth attendants. The SEARCH Team \\
\hline Bhandari et al. 2005 [50] & $\begin{array}{l}\text { A pilot test of the addition of zinc to the current case management package of diarrhea in a } \\
\text { primary health care setting }\end{array}$ \\
\hline Sircar et al. 1991 [51] & $\begin{array}{l}\text { An operational study on implementation of oral rehydration therapy in a rural community } \\
\text { of West Bengal, India }\end{array}$ \\
\hline Benavides et al. 1994 [52] & An operational evaluation of the Community Oral Rehydration Units in Peru \\
\hline Gupta et al. 1994 [53] & $\begin{array}{l}\text { Implementation of oral rehydration therapy (ORT): some problems encountered in training } \\
\text { of health workers during an operational research programme }\end{array}$ \\
\hline
\end{tabular}


Table 2. Continued

\begin{tabular}{|c|c|c|}
\hline DISEASE(s) & Author & TIILE \\
\hline \multirow[t]{9}{*}{$\begin{array}{l}\text { Malaria and } \\
\text { pneumonia }\end{array}$} & Kalyango et al. 2013 [54] & $\begin{array}{l}\text { High adherence to antimalarials and antibiotics under integrated community case manage- } \\
\text { ment of illness in children less than five years in eastern Uganda }\end{array}$ \\
\hline & Chinbua et al. 2012 [55] & $\begin{array}{l}\text { Impact of community management of fever (using antimalarials with or without antibiotics) } \\
\text { on childhood mortality: a cluster-randomized controlled trial in Ghana }\end{array}$ \\
\hline & Mukanga et al. 2012 [56] & $\begin{array}{l}\text { Integrated community case management of fever in children under five using rapid diagnos- } \\
\text { tic tests and respiratory rate counting: a multi-country cluster randomized trial }\end{array}$ \\
\hline & Kalyango et al. 2012 [57] & $\begin{array}{l}\text { Increased use of community medicine distributors and rational use of drugs in children less } \\
\text { than five years of age in Uganda caused by integrated community case management of fever }\end{array}$ \\
\hline & Seidenberg et al. 2012 [58] & $\begin{array}{l}\text { Impact of integrated community case management on health-seeking behavior in rural Zam- } \\
\text { bia }\end{array}$ \\
\hline & Kalyango et al. 2012 [59] & $\begin{array}{l}\text { Performance of community health workers under integrated community case management } \\
\text { of childhood illnesses in eastern Uganda }\end{array}$ \\
\hline & Hamer et al. 2012 [60] & $\begin{array}{l}\text { Quality and safety of integrated community case management of malaria using rapid diag- } \\
\text { nostic tests and pneumonia by community health workers }\end{array}$ \\
\hline & Mukanga et al. 2011 [61] & $\begin{array}{l}\text { Can lay community health workers be trained to use diagnostics to distinguish and treat ma- } \\
\text { laria and pneumonia in children? Lessons from rural Uganda }\end{array}$ \\
\hline & Yeboah-Antwi et al. 2010 [62] & $\begin{array}{l}\text { Community case management of fever due to malaria and pneumonia in children under five } \\
\text { in Zambia: a cluster randomized controlled trial }\end{array}$ \\
\hline $\begin{array}{l}\text { Malaria and } \\
\text { diarrhoea }\end{array}$ & Littrell et al. 2013 [63] & $\begin{array}{l}\text { Narrowing the treatment gap with equitable access: mid-term outcomes of a community case } \\
\text { management program in Cameroon }\end{array}$ \\
\hline \multirow[t]{3}{*}{$\begin{array}{l}\text { Diarrhoea and } \\
\text { Pneumonia }\end{array}$} & Puett et al. 2012 [64] & $\begin{array}{l}\text { Does greater workload lead to reduced quality of preventive and curative care among com- } \\
\text { munity health workers in Bangladesh? }\end{array}$ \\
\hline & Ghimire et al. 2010 [65] & $\begin{array}{l}\text { Community-based interventions for diarrhoeal diseases and acute respiratory infections in } \\
\text { Nepal }\end{array}$ \\
\hline & Cesar et al. 2002 [66] & $\begin{array}{l}\text { Changes in child health indicators in a municipality with community health workers: the } \\
\text { case of Itapirapuă Paulista, Vale do Ribeira, Săo Paulo State, Brazil }\end{array}$ \\
\hline \multirow[t]{7}{*}{$\begin{array}{l}\text { Malaria, pneumo- } \\
\text { nia and diarrhoea }\end{array}$} & Mugeni et al. 2014 [67] & $\begin{array}{l}\text { Nationwide implementation of integrated community case management of childhood illness } \\
\text { in Rwanda }\end{array}$ \\
\hline & Yansaneh et al. 2014 [68] & $\begin{array}{l}\text { Influence of community health volunteers on care seeking and treatment coverage for com- } \\
\text { mon childhood illnesses in the context of free health care in rural Sierra Leone }\end{array}$ \\
\hline & Miller et al. 2014 [69] & $\begin{array}{l}\text { Integrated community case management of childhood illness in Ethiopia: implementation } \\
\text { strength and quality of care }\end{array}$ \\
\hline & Langston et al. 2014 [70] & $\begin{array}{l}\text { Plausible role for community health worker (CHW) peer support groups in increasing care- } \\
\text { seeking in an integrated community case management project in Rwanda: a mixed methods } \\
\text { evaluation }\end{array}$ \\
\hline & Lainez et al. 2012 [71] & Insights from community case management data in six sub-Saharan African countries \\
\hline & Cardemil et al. 2012 [72] & $\begin{array}{l}\text { Comparison of methods for assessing quality of care for community case management of sick } \\
\text { children: an application with community health workers in Malawi }\end{array}$ \\
\hline & Chandani et. al 2012 [73] & $\begin{array}{l}\text { Factors affecting availability of essential medicines among community health workers in Ethi- } \\
\text { opia, Malawi, and Rwanda: solving the last mile puzzle }\end{array}$ \\
\hline
\end{tabular}

ample of integrated care in health facilities under IMCI to also become integrated in the community [4].

Meanwhile, interventions in the private sector have focused on malaria alone. This follows the historical pattern of Home Management of Malaria, and the hitherto sole malaria focus of major funders and initiatives such as the Global Fund's Affordable Medicine Facility malaria (AMFm) [14]. From a point of quality of care to the individual sick child, as well as to make drug use more rational, it seems logical to integrate service delivery for acute febrile illness for the main causes of fever to provide alternative appropriate treatment where malaria diagnostics are negative. Here, the iCCM strategy is one vehicle. The current Global Fund application round has not quite reached integrated care of febrile illness, but it opens the door to integration with other funders towards integrated management. In March 2014, a joint statement was signed by UNICEF, Global Fund and the RMNCH Strategy Coordination Team, expressing an intention to strengthen coordination around the implementation and financing of the integration agenda, with a focus on iCCM.

However, there have been many efforts to improve quality of care in the private sector. Shah et al. reviewed the experience with different interventions, finding limited effect of the most widely used intervention model -training - suggesting to include also incentives and accountability [76]. Social franchising allows a network of independently operated health outlets to provide services and commodities to clients with oversight by a coordinating agency [77]. It provides business incentive for the health outlets and increases ac- 
countability [78], but further research is needed on the effect of social franchising on quality of care [79]. Meanwhile, the equity aspects of private sector interventions need to be clarified [80]. Also, private providers become quite context specific, requiring context-relevant interventions [8]. This implies need for further research on ICCM in private sector, and the utility of iCCM in private sector interventions, within a context of implementation research in conjunction with programs in different setting $[24,81]$, along the lines of WHOs on-going RaCE evaluation of community health worker iCCM implementation [82].

A possible limitation of this review is that even though we tried to include all available literature/publications, some literature may not have been accessed, especially the most recent.

\section{CONCLUSION}

While the private sector is an important source of care for children in low income countries, little has been done to harness the potential of this sector in improving access to care for non-malaria fever in children within the community. It is important for interventions and research within the private sector to provide integrated care for sick children, and not only focus on care for malaria. The iCCM strategy has the potential to act as a vehicle to improve both quality of care and make drug use more rational in the private sector, provided appropriate modification is done to reflect private sector specificities. It is also logical for iCCM programs to expand their activities to include the private sector to achieve higher population coverage. An implementation research agenda for private sector integrated care of febrile childhood illness needs to be developed and implemented in conjunction with private sector intervention programs.

Funding: No funding was directly sought for this review.

Disclaimer: The views expressed here are solely of the authors and not their institutions.

Authorship contributions: PA, JM, SP designed the study. PA led the review process. PA, SP interpreted the findings. The manuscript was written by PA, and all authors approved the final manuscript.

Competing interests: All authors have completed the Unified Competing Interest form atwww.icmje. org/coi_disclosure.pdf (available on request from the corresponding author). We declare that we have no conflicts of interest.

1 Walker D, Champion C, Hossain S, Wahed T, Gazi R, Koehlmoos T, et al. Establishing non-state sector research priorities in developing countries using a participatory methodology. Geneva: Alliance for Health Policy and Systems Research and WHO, 2009. Available at: http://www.who.int/alliance-hpsr/projects/alliancehpsr-nonstatepaper.pdf. Accessed: 1 October 2014.

2 Forsberg BC, Montagu D, Sundewall J. Moving towards in-depth knowledge on the private health sector in low-and middle-income countries. Health Policy Plan. 2011;26 Suppl 1:i1-3. Medline:21729912 doi:10.1093/ heapol/czr050

3 Forsberg BC, Montagu D. Further advances in knowledge on the role of the private sector in health systems. Health Policy Plan. 2014;29 Suppl 1:il-3. Medline:25012793 doi:10.1093/heapol/czu018

4 Young M, Wolfheim C, Marsh DR, Hammamy D. World Health Organization/United Nations Children's Fund joint statement on integrated community case management: An equity-focused strategy to improve access to essential treatment services for children. Am J Trop Med Hyg. 2012;87(5 Suppl):6-10. Medline:23136272 doi:10.4269/ajtmh.2012.12-0221

5 Littrell M, Gatakaa H, Evance I, Poyer S, Njogu J, Solomon T, et al. Monitoring fever treatment behaviour and equitable access to effective medicines in the context of initiatives to improve ACT access: baseline results and implications for programming in six African countries. Malar J. 2011;10:327. Medline:22039892 doi:10.1186/1475-2875-10-327

6 Rutebemberwa E, Pariyo G, Tomson G, Kallander K. Utilization of public or private health care providers by febrile children after user fee removal in Uganda. Malar J. 2009;8:45. Medline:19284673 doi:10.1186/1475-28758-45

7 Awor P, Wamani H, Bwire G, Jagoe G, Peterson S. Private sector drug shops in integrated community case management of malaria, pneumonia, and diarrhea in children in Uganda. Am J Trop Med Hyg. 2012;87(5 Suppl):92-6. Medline:23136283 doi:10.4269/ajtmh.2012.11-0791

8 Gautham M, Shyamprasad KM, Singh R, Zachariah A, Singh R, Bloom G. Informal rural healthcare providers in North and South India. Health Policy Plan. 2014;29 Suppl 1:i20-9. Medline:25012795 doi:10.1093/heapol/ czt050 
9 Hetzel MW, Dillip A, Lengeler C, Obrist B, Msechu JJ, Makemba AM. Malaria treatment in the retail sector: knowledge and practices of drug sellers in rural Tanzania. BMC Public Health. 2008;8:157. Medline:18471299 doi:10.1186/1471-2458-8-157

10 Moher D, Liberati A, Tetzlaff J, Altman DG. PRISMA Group. Preferred reporting items for systematic reviews and meta-analyses: the PRISMA statement. BMJ. 2009;339:b2535. Medline:19622551 doi:10.1136/bmj.b2535

11 Thomson R, Festo C, Johanes B, Kalolella A, Bruxvoort K, Nchimbi H. Has Tanzania embraced the green leaf? Results from outlet and household surveys before and after implementation of the Affordable Medicines Facility-malaria. PLoS ONE. 2014;9:e95607. Medline:24816649

12 Ikwuobe JO, Faragher BE, Alawode G, Lalloo DG. The impact of rapid malaria diagnostic tests upon anti-malarial sales in community pharmacies in Gwagwalada, Nigeria. Malar J. 2013;12:380. Medline:24172163 doi:10.1186/1475-2875-12-380

13 Kangwana BP, Kedenge SV, Noor AM, Alegana VA, Nyandigisi AJ, Pandit J, et al. The effect of an anti-malarial subsidy programme on the quality of service provision of artemisinin-based combination therapy in Kenya: a cluster-randomized, controlled trial. Malar J. 2013;12:81. Medline:23452547 doi:10.1186/1475-2875-12-81

14 Tougher S; ACTwatch Group, Ye Y, Amuasi JH, Kourgueni IA, Thomson R, et al. Effect of the Affordable Medicines Facility - malaria (AMFm) on the availability, price, and market share of quality-assured artemisinin-based combination therapies in seven countries: a before-and-after analysis of outlet survey data. Lancet. 2012;380:191626. Medline:23122217 doi:10.1016/S0140-6736(12)61732-2

15 Talisuna AO, Daumerie PG, Balyeku A, Egan T, Piot B, Coghlan R, et al. Closing the access barrier for effective anti-malarials in the private sector in rural Uganda: consortium for ACT private sector subsidy (CAPSS) pilot study. Malar J. 2012;11:356. Medline:23107021 doi:10.1186/1475-2875-11-356

16 Yeung S, Patouillard E, Allen H, Socheat D. Socially-marketed rapid diagnostic tests and ACT in the private sector: ten years of experience in Cambodia. Malar J. 2011;10:243. Medline:21851625 doi:10.1186/1475-2875$10-243$

17 Littrell M, Gatakaa H, Phok S, Allen H, Yeung S, Chuor CM, et al. Case management of malaria fever in Cambodia: results from national anti-malarial outlet and household surveys. Malar J. 2011;10:328. Medline:22039922 doi:10.1186/1475-2875-10-328

18 Rutta E, Kibassa B, McKinnon B, Liana J, Mbwasi R, Mlaki W, et al. Increasing access to subsidized artemisininbased combination therapy through accredited drug dispensing outlets in Tanzania. Health Res Policy Syst. 2011;9:22. Medline:21658259 doi:10.1186/1478-4505-9-22

19 Kangwana BP, Kedenge SV, Noor AM, Alegana VA, Nyandigisi AJ, Pandit J, et al. The impact of retail-sector delivery of artemether-lumefantrine on malaria treatment of children under five in Kenya: a cluster randomized controlled trial. PLoS Med. 2011;8:e1000437. Medline:21655317 doi:10.1371/journal.pmed.1000437

20 Alba S, Dillip A, Hetzel MW, Mayumana I, Mshana C, Makemba A, et al. Improvements in access to malaria treatment in Tanzania following community, retail sector and health facility interventions - a user perspective. Malar J. 2010;9:163. Medline:20550653 doi:10.1186/1475-2875-9-163

21 Abuya TO, Fegan G, Amin AA, Akhwale WS, Noor AM, Snow RW, et al. Evaluating different dimensions of programme effectiveness for private medicine retailer malaria control interventions in Kenya. PLoS ONE. 2010;5:e8937. Medline:20126620 doi:10.1371/journal.pone.0008937

22 Larson CP, Koehlmoos TP, Sack DA; Abuya TO, Abuya TO, Abuya TO, Scaling Up of Zinc for Young Children (SUZY) Project Team CP. Scaling up zinc treatment of childhood diarrhoea in Bangladesh: theoretical and practical considerations guiding the SUZY Project. Health Policy Plan. 2012;27:102-14. Medline:21343236 doi:10.1093/heapol/czr015

23 Awor P, Wamani H, Tyyleskar T, Jagoe G, Peterson S. Increased access to care and appropriateness of treatment at private sector drug shops with integrated management of malaria, pneumonia and diarrhoea: a quasi-experimental study in Uganda. PLoS ONE. 2014, in press.

24 Population Services International. Integrated case management. Available from: http://www.psi.org/our-work/ healthy-lives/interventions/ccmimpact-program. Accessed: 27 August 2014.

25 Siekmans K, Sohani S, Kisia J, Kiilu K, Wamalwa E, Nelima F, et al. Community case management of malaria: a pro-poor intervention in rural Kenya. Int Health. 2013;5:196-204. Medline:24030270 doi:10.1093/inthealth/ iht017

26 Ndiaye Y, Ndiaye JL, Cisse B, Blanas D, Bassene J, Manga IA, et al. Community case management in malaria: review and perspectives after four years of operational experience in Saraya district, south-east Senegal. Malar J. 2013;12:240. Medline:23849053 doi:10.1186/1475-2875-12-240

27 Blanas DA, Ndiaye Y, Nichols K, Jensen A, Siddiqui A, Hennig N. Barriers to community case management of malaria in Saraya, Senegal: training, and supply-chains. Malar J. 2013;12:95. Medline:23497188 doi:10.1186/1475-2875-12-95

28 Thiam S, Thwing J, Diallo I, Fall FB, Diouf MB, Perry R, et al. Scale-up of home-based management of malaria based on rapid diagnostic tests and artemisinin-based combination therapy in a resource-poor country: results in Senegal. Malar J. 2012;11:334. Medline:23009244 doi:10.1186/1475-2875-11-334

29 Lim S, Yasuoka J, Poudel KC, Ly P, Nguon C, Jimba M. Promoting community knowledge and action for malaria control in rural Cambodia: potential contributions of Village Malaria Workers. BMC Res Notes. 2012;5:405. Medline:22863397 doi:10.1186/1756-0500-5-405 
30 Tine RC, Faye B, Ndour CT, Ndiaye JL, Ndiaye M, Bassene C, et al. Impact of combining intermittent preventive treatment with home management of malaria in children less than 10 years in a rural area of Senegal: a cluster randomized trial. Malar J. 2011;10:358. Medline:22166001 doi:10.1186/1475-2875-10-358

31 Chanda P, Hamainza B, Moonga HB, Chalwe V, Pagnoni F. Community case management of malaria using ACT and RDT in two districts in Zambia: achieving high adherence to test results using community health workers. Malar J. 2011;10:158. Medline:21651827 doi:10.1186/1475-2875-10-158

32 Mubi M, Janson A, Warsame M, Mírtensson A, Källander K, Petzold MG, et al. Malaria rapid testing by community health workers is effective and safe for targeting malaria treatment: randomised cross-over trial in Tanzania. PLoS ONE. 2011;6:e19753. Medline:21750697 doi:10.1371/journal.pone.0019753

33 Nsungwa-Sabiiti J, Peterson S, Pariyo G, Ogwal-Okeng J, Petzold MG, Tomson G. Home-based management of fever and malaria treatment practices in Uganda. Trans R Soc Trop Med Hyg. 2007;101:1199-207. Medline:17945320 doi:10.1016/j.trstmh.2007.08.005

34 Chinbuah AM, Gyapong JO, Pagnoni F, Wellington EK, Gyapong M. Feasibility and acceptability of the use of artemether-lumefantrine in the home management of uncomplicated malaria in children 6-59 months old in Ghana. Trop Med Int Health. 2006;11:1003-16. Medline:16827701 doi:10.1111/j.1365-3156.2006.01654.x

35 Kolaczinski JH, Ojok N, Opwonya J, Meek S, Collins A. Adherence of community caretakers of children to prepackaged antimalarial medicines (HOMAPAK) among internally displaced people in Gulu district, Uganda. Malar J. 2006;5:40. Medline:16700903 doi:10.1186/1475-2875-5-40

36 Kidane G, Morrow RH. Teaching mothers to provide home treatment of malaria in Tigray, Ethiopia: a randomised trial. Lancet. 2000;356:550-5. Medline:10950232 doi:10.1016/S0140-6736(00)02580-0

37 Kalyango JN, Alfven T, Peterson S, Mugenyi K, Karamagi C, Rutebemberwa E. Integrated community case management of malaria and pneumonia increases prompt and appropriate treatment for pneumonia symptoms in children under five years in Eastern Uganda. Malar J. 2013;12:340. Medline:24053172 doi:10.1186/1475-2875-12-340

38 Noordam AC, Barberá Laínez Y, Sadruddin S, van Heck PM, Chono AO, Acaye GL, et al. The use of counting beads to improve the classification of fast breathing in low-resource settings: a multi-country review. Health Policy Plan. 2014;pii:czu047. Epub ahead of print. Medline:24974104

39 Bari A, Sadruddin S, Khan A, Khan Iu, Khan A, Lehri IA, et al. Community case management of severe pneumonia with oral amoxicillin in children aged 2-59 months in Haripur district, Pakistan: a cluster randomised trial. Lancet. 2011;378:1796-803. Medline:22078721 doi:10.1016/S0140-6736(11)61140-9

40 Soofi S, Ahmed S, Fox MP, MacLeod WB, Thea DM, Qazi SA, et al. Effectiveness of community case management of severe pneumonia with oral amoxicillin in children aged 2-59 months in Matiari district, rural Pakistan: a cluster-randomised controlled trial. Lancet. 2012;379:729-37. Medline:22285055 doi:10.1016/S01406736(11)61714-5

41 Sylla A, Gučye EH, N'diaye O, Sarr CS, Ndiaye D, Diouf S, et al. Low level educated community health workers training: a strategy to improve children access to acute respiratory treatment in Senegal. [in French]. Arch Pediatr. 2007;14:244-8. Medline:17175144 doi:10.1016/j.arcped.2006.11.022

42 Källander K, Tomson G, Nsabagasani X, Sabiiti JN, Pariyo G, Peterson S. Can community health workers and caretakers recognise pneumonia in children? Experiences from western Uganda. Trans R Soc Trop Med Hyg. 2006;100:956-63. Medline:16455119 doi:10.1016/j.trstmh.2005.11.004

43 Hadi A. Diagnosis of pneumonia by community health volunteers: experience of BRAC, Bangladesh. Trop Doct. 2001;31:75-7. Medline:11321276

44 Mehnaz A, Billoo AG, Yasmeen T, Nankani K. Detection and management of pneumonia by community health workers—a community intervention study in Rehri village, Pakistan. J Pak Med Assoc. 1997;47:42-5. Medline:9071859

45 Bang AT, Bang RA, Tale O, Sontakke P, Solanki J, Wargantiwar R, et al. Reduction in pneumonia mortality and total childhood mortality by means of community-based intervention trial in Gadchiroli, India. Lancet. 1990;336:201-6. Medline:1973770 doi:10.1016/0140-6736(90)91733-Q

46 Khan AJ, Khan JA, Akbar M, Addiss DG. Acute respiratory infections in children: a case management intervention in Abbottabad District, Pakistan. Bull World Health Organ. 1990;68:577-85. Medline:2289294

47 Fagbule D, Parakoyi DB, Spiegel R. Acute respiratory infections in Nigerian children: prospective cohort study of incidence and case management. J Trop Pediatr. 1994;40:279-84. Medline:7807622 doi:10.1093/ tropej/40.5.279

48 Bang AT, Bang RA, Morankar VP, Sontakke PG, Solanki JM. Pneumonia in neonates: can it be managed in the community? Arch Dis Child. 1993;68(5 Spec No):550-6. Medline:8323354 doi:10.1136/adc.68.5_Spec_No.550

49 Bang AT, Bang RA, Sontakke PG. Management of childhood pneumonia by traditional birth attendants. The SEARCH Team. Bull World Health Organ. 1994;72:897-905. Medline:7867135

50 Bhandari N, Mazumder S, Taneja S, Dube B, Black RE, Fontaine O, et al. A pilot test of the addition of zinc to the current case management package of diarrhea in a primary health care setting. J Pediatr Gastroenterol Nutr. 2005;41:685-7. Medline:16254536 doi:10.1097/01.mpg.0000182799.69675.92

51 Sircar BK, Deb BC, Sengupta PG, Mondal S, Gupta DN, Sarkar S, et al. An operational study on implementation of oral rehydration therapy in a rural community of West Bengal, India. Indian J Med Res. 1991;93:297-302. Medline: 1778617 
52 Benavides BM, Jacoby ER. An operational evaluation of the Community Oral Rehydration Units in Peru. Health Policy Plan. 1994;9:438-43. Medline:10139476 doi:10.1093/heapol/9.4.438

53 Gupta DN, SenGupta PG, Sircar BK, Mondal S, Sarkar S, Deb BC. Implementation of ORT: some problems encountered in training of health workers during an operational research programme. Indian J Public Health. 1994;38:69-72. Medline:7836000

54 Kalyango JN, Rutebemberwa E, Karamagi C, Mworozi E, Ssali S, Alfven T, et al. High adherence to antimalarials and antibiotics under integrated community case management of illness in children less than five years in eastern Uganda. PLoS ONE. 2013;8:e60481. Medline:23555980 doi:10.1371/journal.pone.0060481

55 Chinbuah MA, Kager PA, Abbey M, Gyapong M, Awini E, Nonvignon J, et al. Impact of community management of fever (using antimalarials with or without antibiotics) on childhood mortality: a cluster-randomized controlled trial in Ghana. Am J Trop Med Hyg. 2012;87(5 Suppl):11-20. Medline:23136273 doi:10.4269/ajtmh.2012.12-0078

56 Mukanga D, Tiono AB, Anyorigiya T, Källander K, Konaté AT, Oduro AR, et al. Integrated community case management of fever in children under five using rapid diagnostic tests and respiratory rate counting: a multi-country cluster randomized trial. Am J Trop Med Hyg. 2012;87(5 Suppl):21-9. Medline:23136274 doi:10.4269/ ajtmh.2012.11-0816

57 Kalyango JN, Lindstrand A, Rutebemberwa E, Ssali S, Kadobera D, Karamagi C, et al. Increased use of community medicine distributors and rational use of drugs in children less than five years of age in Uganda caused by integrated community case management of fever. Am J Trop Med Hyg. 2012;87(5 Suppl):36-45. Medline:23136276 doi:10.4269/ajtmh.2012.11-0733

58 Seidenberg PD, Hamer DH, Iyer H, Pilingana P, Siazeele K, Hamainza B, et al. Impact of integrated community case management on health-seeking behavior in rural Zambia. Am J Trop Med Hyg. 2012;87(5 Suppl):105-10. Medline:23136285 doi:10.4269/ajtmh.2012.11-0799

59 Kalyango JN, Rutebemberwa E, Alfven T, Ssali S, Peterson S, Karamagi C. Performance of community health workers under integrated community case management of childhood illnesses in eastern Uganda. Malar J. 2012;11:282. Medline:22905758 doi:10.1186/1475-2875-11-282

60 Hamer DH, Brooks ET, Semrau K, Pilingana P, MacLeod WB, Siazeele K, et al. Quality and safety of integrated community case management of malaria using rapid diagnostic tests and pneumonia by community health workers. Pathog Glob Health. 2012;106:32-9. Medline:22595272 doi:10.1179/1364859411Y.0000000042

61 Mukanga D, Babirye R, Peterson S, Pariyo GW, Ojiambo G, Tibenderana JK, et al. Can lay community health workers be trained to use diagnostics to distinguish and treat malaria and pneumonia in children? Lessons from rural Uganda. Trop Med Int Health. 2011;16:1234-42. Medline:21752163 doi:10.1111/j.1365-3156.2011.02831.x

62 Yeboah-Antwi K, Pilingana P, Macleod WB, Semrau K, Siazeele K, Kalesha P, et al. Community case management of fever due to malaria and pneumonia in children under five in Zambia: a cluster randomized controlled trial. PLoS Med. 2010;7:e1000340. Medline:20877714 doi:10.1371/journal.pmed.1000340

63 Littrell M, Moukam LV, Libite R, Youmba JC, Baugh G. Narrowing the treatment gap with equitable access: midterm outcomes of a community case management program in Cameroon. Health Policy Plan. 2013;28:705-16. Medline:23144228 doi:10.1093/heapol/czs110

64 Puett C, Coates J, Alderman H, Sadruddin S, Sadler K. Does greater workload lead to reduced quality of preventive and curative care among community health workers in Bangladesh? Food Nutr Bull. 2012;33:273-87. Medline: 23424894

65 Ghimire M, Pradhan YV, Maskey MK. Community-based interventions for diarrhoeal diseases and acute respiratory infections in Nepal. Bull World Health Organ. 2010;88:216-21. Medline:20428390 doi:10.2471/ BLT.09.065649

66 Cesar JA, Cavaleti MA, Holthausen RS, de Lima LG. Changes in child health indicators in a municipality with community health workers: the case of Itapirapua Paulista, Vale do Ribeira, Sao Paulo State, Brazil. [in Portuguese]. Cad Saude Publica. 2002;18:1647-54. Medline:12488892 doi:10.1590/S0102-311X2002000600019

67 Mugeni C, Levine AC, Munyaneza RM, Mulindahabi E, Cockrell HC, Glavis-Bloom J, et al. Nationwide implementation of integrated community case management of childhood illness in Rwanda. Glob Health Sci Pract. 2014:2:328-41. Medline:25276592 doi:10.9745/GHSP-D-14-00080

68 Yansaneh AI, Moulton LH, George AS, Rao SR, Kennedy N, Bangura P, et al. Influence of community health volunteers on care seeking and treatment coverage for common childhood illnesses in the context of free health care in rural Sierra Leone. Trop Med Int Health. 2014. Epub ahead of print. Medline:25243929 doi:10.1111/tmi.12383

69 Miller NP, Amouzou A, Tafesse M, Hazel E, Legesse H, Degefie T, et al. Integrated community case management of childhood illness in Ethiopia: implementation strength and quality of care. Am J Trop Med Hyg. 2014;91:42434. Medline:24799369 doi:10.4269/ajtmh.13-0751

70 Langston A, Weiss J, Landegger J, Pullum T, Morrow M, Kabadege M, et al. Plausible role for CHW peer support groups in increasing care-seeking in an integrated community case management project in Rwanda: a mixed methods evaluation. Glob Health Sci Pract. 2014;2:342-54. Medline:25276593 doi:10.9745/GHSP-D-14-00067

71 Laínez YB, Wittcoff A, Mohamud AI, Amendola P, Perry HB, D'Harcourt E. Insights from community case management data in six sub-Saharan African countries. Am J Trop Med Hyg. 2012;87(5 Suppl):144-50. Medline:23136290 doi:10.4269/ajtmh.2012.12-0106

72 Cardemil CV, Gilroy KE, Callaghan-Koru JA, Nsona H, Bryce J. Comparison of methods for assessing quality of care for community case management of sick children: an application with community health workers in Malawi. Am J Trop Med Hyg. 2012;87(5 Suppl):127-36. Medline:23136288 doi:10.4269/ajtmh.2012.12-0389 
73 Chandani Y, Noel M, Pomeroy A, Andersson S, Pahl MK, Williams T. Factors affecting availability of essential medicines among community health workers in Ethiopia, Malawi, and Rwanda: solving the last mile puzzle. Am J Trop Med Hyg. 2012;87(5 Suppl):120-6. Medline:23136287 doi:10.4269/ajtmh.2012.11-0781

74 Källander K, Nsungwa-Sabiiti J, Balyeku A, Pariyo G, Tomson G, Peterson S. Home and community management of acute respiratory infections in children in eight Ugandan districts. Ann Trop Paediatr. 2005;25:283-91. Medline:16297303 doi:10.1179/146532805X72430

75 Sazawal S, Black RE; Pneumonia Case Management Trials Group. Effect of pneumonia case management on mortality in neonates, infants, and preschool children: a meta-analysis of community-based trials. Lancet Infect Dis. 2003;3:547-56. Medline:12954560 doi:10.1016/S1473-3099(03)00737-0

76 Shah NM, Brieger WR, Peters DH. Can interventions improve health services from informal private providers in low and middle-income countries?: a comprehensive review of the literature. Health Policy Plan. 2011;26:27587. Medline:21097784 doi:10.1093/heapol/czq074

77 Bishai DM, Shah NM, Walker DG, Brieger WR, Peters DH. A social franchising to improve quality and access in private health care in developing countries. Harvard Health Policy Review. 2008;9:184-97.

78 Montagu D. Franchising of health services in low-income countries. Health Policy Plan. 2002;17:121-30. Medline:12000772 doi:10.1093/heapol/17.2.121

79 Koehlmoos TP, Gazi R, Hossain SS, Zaman K. The effect of social franchising on access to and quality of health services in low- and middle-income countries. Cochrane Database Syst Rev. 2009;(1):CD007136. Medline: 19160323

80 Patouillard E, Goodman CA, Hanson KG, Mills AJ. Can working with the private for-profit sector improve utilization of quality health services by the poor? A systematic review of the literature. Int J Equity Health. 2007;6:17. Medline:17988396 doi:10.1186/1475-9276-6-17

81 UNITAID. Innovative financing to shape markets for HIV/AIDS, malaria and tuberculosis. 2013. Available at: http://www.unitaid.eu/en/creating-a-private-sector-market-for-quality-assured-rdts-in-malaria-endemiccountries. Accessed: 1 November 2014.

82 World Health Organisation. Rapid Access Expansion 2015 programme (RAcE 2015) 2014. Available at: http:// www.who.int/malaria/areas/rapid_access_expansion_2015/en/. Accessed: 24 August 2014. 